John Carroll University

Carroll Collected

History

Summer 1999

\title{
Cultivation, Conservatism, and the Early National Gentry: The Manigault Family and their Circle
}

Daniel P. Kilbride

John Carroll University, dkilbride@jcu.edu

Follow this and additional works at: http:// collected.jcu.edu/hist-facpub

Part of the History Commons

\section{Recommended Citation}

Kilbride, Daniel P., "Cultivation, Conservatism, and the Early National Gentry: The Manigault Family and their Circle" (1999).

History. 7.

http://collected.jcu.edu/hist-facpub/7

This Book Review is brought to you for free and open access by Carroll Collected. It has been accepted for inclusion in History by an authorized administrator of Carroll Collected. For more information, please contact connell@jcu.edu. 


\section{GULTIVATION,}

CONSERVATISM, AND

THE EARLY NATIONAL

GENTRY: THE

MANIGAULT FAMILY AND

THEIR GIRGLE

\section{Daniel Kilbride}

In 1807, Alice Izard explained her inability to decide on a permanent residence by confessing to her daughter that " $[\mathrm{m}] \mathrm{y}$ heart is divided. It is sometimes in Philadelphia, sometimes in Charleston." She and her daughter, Margaret Izard Manigault, soon chose to live in Philadelphia, a decision ratified by the subsequent relocation of other family members and the frequent visits of Carolina friends and relations. Once established in the city on the Delaware they engaged in social affairs designed to counter democratizing trends by asserting the virtues of privilege and reinforcing the cohesion of the privileged class. This essay focuses on two types of these activities: the social call and, in particular, the salon. The family's determination in relocating to Philadelphia and establishing a salon is understandable only in the context of changes within the postrevolutionary American aristocracy. Social events, particularly their intellectual gatherings, were not private affairs. They represented a reactionary effort to redefine and reassert the merits of the Federalist elite, a project of particular moment after the debacle of 1800 . Federalist elites viewed that Republican victory as "an attack on the core values of American society and on the Federalist claims as defender of the national welfare," as Albrecht Koschnik observes. Moreover, the regionally diverse Manigault

Daniel Kilbride is assistant professor of history at John Carroll University in Cleveland, Ohio. He wishes to thank Cynthia Kierner and Stephanie Cole for their comments on an early version of this essay presented to the meeting of the Southern Association of Women Historians at Charleston, South Carolina, June 13, 1997. 
circle in Philadelphia represented, in concrete form, the foundations of a genuine American upper class. ${ }^{1}$

The divided heart of Alice Izard sheds light on two developments of the early republic just now attracting the attention of historians. The first, and the primary focus of this article, involves the creative response of conservative social elites, largely Federalists, to attacks on their social, political, and cultural legitimacy during what Gordon Wood has characterized as the "assault on aristocracy" of the postrevolutionary period. Although the investigation of the social history of the rich is a historical project of considerable merit in its own right, this essay analyzes those practices for another purpose. The social lives, manners, and "private" values of the Manigaults and their circle illuminate an issue of some moment to historians of political culture: the expansion of the realm of politics and political action into areas once delegated private or merely social. Historians of early American politics and culture are just beginning to understand what the Manigault women knew implicitly: that associating, conversing, and even dancing were not merely private acts but political practices. ${ }^{2}$

The establishment of the Manigault salon was a public, political act. It was, in large part, a response to the declining fortunes of the Federalist establishment that, these women believed, emerged from the failure of American aristocrats to propagate effectively the virtues of elitism. In 1965, David Hackett Fischer showed how, after their party's drubbing in 1800 , "young Federalists" moved to modernize their party into a more effective, Republican-style electoral machine. More recently, historians have analyzed how civic celebrations and other public rituals "can act to

1 Alice Izard to Margaret Manigault, Nov. 11, 1807, Manigault Family Papers, South Caroliniana Library, University of South Carolina, Columbia, SC, (South Carolina Historical Society Series 55-2), microfiche copy at the University of Florida Library, Gainesville (hereafter Manigault Family Papers); Albrecht Koschnik, "Political Conflict and Public Contest: Rituals of National Celebration in Philadelphia, 1788-1815," Pennsylvania Magazine of History and Biography, 118 (July 1994), 241.

2 Gordon S. Wood, The Radicalism of the American Revolution (New York, 1992), 187-96; Saul Cornell, "Aristocracy Assailed: The Ideology of Backcountry AntiFederalism," Journal of American History, 76 (Mar. 1990), 1148-72. Recent works on manners and comportment in the early national period include John M. Kasson, Rudeness and Civility: Manners in Nineteenth-Century Urban America (New York, 1990); Richard L. Bushman, The Refinement of America: Persons, Houses, Cities (New York, 1992); C. Dallett Hemphill, "Middle Class Rising in Revolutionary America: The Evidence from Manners," Journal of Social History, 30 (Winter 1997), 317-44; and Jacquelyn C. Miller, "An 'Uncommon Tranquility of Mind': Emotional Self-Control and the Construction of Middle-Class Identity in Eighteenth-Century Philadelphia," ibid., 30 (Fall 1997), 129-48. 
reorganize [social arrangements] or even help to create them." This article takes a different tack. By focusing on ostensibly "private" affairs, particularly salons, as alternative means of political expression, this essay contributes to and refines an ongoing revision of our understanding of political culture in the early republic that emphasizes political practices-what David Waldstreicher calls "the everyday interplay of rhetoric, ritual, and political action." Like the creation of a more cohesive party structure, the rise of electioneering, Washington's Birthday balls, and political dueling, the Manigault family's salons represented a form of Federalist political performance that sought to relegitimize both Federalism and conservatism for a new century. The ostensibly private rituals of the Manigaults - their social visits, parties, and the salons-are full of meaning for understanding the redefinition of Federalism and elitism in the early American republic. Upon learning of Madison's crushing defeat of Charles C. Pinckney in 1808, Alice Izard hoped for "some unexpected event [that] should suddenly open the eyes of the blind." What distinguishes the Manigaults from the social elites of the Jacksonian era is that they did more than pine for past glories and hope for a miracle to revive their fortunes-they acted. ${ }^{3}$

A secondary, related aim of this essay is to explain how the Manigaults participated in and helped establish an American elite culture that transcended regional boundaries. This leisure-class network is only now emerging from the shadow of social historians' studies of the dispossessed. One effect of that altogether necessary effort has been a relative paucity of works on American elites. Not much has changed since 1973, when

${ }^{3}$ Alice Izard to Margaret Manigault, Dec. 7, 1808, Manigault Family Papers; David Waldstreicher, In the Midst of Perpetual Fetes: The Making of American Nationalism, 17761820 (Chapel Hill, 1997), 3; Sally Falk Moore and Barbara G. Myerhoff, "Introduction" in Moore and Myerhoff, eds., Secular Ritual: Forms and Meaning (Assen, Netherlands, 1977), 5; David Hackett Fischer, The Revolution of American Conservatism: The Federalist Party in the Era of Jeffersonian Democracy (New York, 1965). Recent examinations of practices as windows into political culture include, in addition to Waldstreicher, David S. Shields, Civil Tongues and Polite Letters in British America (Chapel Hill, 1997); Len Travers, Celebrating the Fourth: Independence Day and the Rites of Nationalism in the Early Republic (Amherst, 1997); Simon P. Newman, Parades and the Politics of the Street: Festive Culture in the Early American Republic (Philadelphia, 1997); Joanne Freeman, "Dueling as Politics: Reinterpreting the Burr-Hamilton Duel," William and Mary Quarterly, 53 (Apr. 1996), 289-3 $\rightarrow$ Bertram Wyatt-Brown, "Andrew Jackson's Honor," Journal of the Early Republic, 17 (Spring 1997), 1-36; and Albrecht Koschnik, "Fashioning a Federalist Self: Young Men and Voluntary Association in Early Nineteenth-Century Philadelphia," paper presented to the seminar of the Philadelphia Center for Early American Studies, October 24, 1997. 
Edward Pessen called "the private world of the antebellum urban elite ... a tricky and largely unexplored terrain." Much of this inattention must be laid at the feet of elites themselves. Most historians find it difficult to sympathize with the privileged, particularly when they complain that they are not privileged enough. E.P. Thompson suggested that elites in decline often contrast a romanticized version of an old order-the "good old days"- to a similarly caricatured period of contemporary "vulgarity" to rationalize their own decline. Visions of declension, according to Thompson, are usually articulated "less as actuality than as a model of an antique, recently passed, golden age from which present modes and manners are a degeneration." There is much to be said for this argument. Nevertheless, at least some bluebloods-the Manigault and Izard women among them-sincerely believed that privileged orders were an essential component to any great civilization, especially a republican one. They advanced a thoroughly reactionary vision of American politics and culture that, they thought, combined old world refinement with new world republicanism. In their America, an aristocracy combining birth and merit, purged of European decadence, ruled with the approbation of deferential lower orders. ${ }^{4}$

As they did for other privileged families, the Manigaults' private rituals served as the ideological foundations of their commitment to elitism. These rites and traditions had regional permutations but they were essentially American. To their genteel peers, the family's southern roots-and the slave laborers that served as the basis of their fortunes-

${ }^{4}$ Edward Pessen, Riches, Class, and Power Before the Civil War (Lexington, MA, 1973), 221; E.P. Thompson, "Eighteenth Century English Society: Class Struggle Without Class?" Social History, 3 (Jan. 1978), 136-37. On the construction of "natural aristocracy," see Waldstreicher, In the Midst of Perpetual Fetes, 67-85. Alan Brinkley might have extended his critique of scholarly inattention to twentieth-century conservatism to this earlier period. See Brinkley, "The Problem of American Conservatism," American Historical Review, 99 (Apr. 1994), 409-29. Works on the upper crust in this era include E. Digby Baltzell, Philadelphia Gentlemen: The Making of a National Upper Class (1958; rep., New Brunswick, NJ, 1989); Frederick Cople Jaher, The Urban Establishment: Upper Strata in Boston, New York, Charleston, Chicago, and Los Angeles (Urbana, 1982); Cynthia A. Kierner, Traders and Gentlefolk: The Livingstons of New York, 1675-1790 (Ithaca, 1992); Martin J. Burke, The Conundrum of Class: Public Discourse on the Social Order in America (Chicago, 1995); and Stuart Blumin, The Emergence of the Middle Class: Social Experience in the American City, 1790-1900 (Cambridge, UK, 1987). Pessen, Riches, Class, and Power is the best known work by far; but see the responses by Robert E. Gallman: "Professor Pessen on the 'Egalitarian Myth,"' Social Science History, 2 (Winter 1978), 194-207; and Gallman, 'The 'Egalitarian Myth,' Once Again." ibid., 5 (Spring 1981), 223-34. 
were at best curiosities. Certainly they were no grounds for censure or social ostracism. Rather, Philadelphia social affairs-those both given and attended by the Manigaults and other southern families-served to maintain a single aristocratic sensibility in the American elite. Growing political and cultural isolation only heightened this sense of common endeavor. Indeed, ties between Philadelphia bluebloods and their southern peers actually grew stronger as the century progressed. From colonial times until the Civil War, northern and southern aristocrats understood that shared manners and tastes signified a commonly held conservative world view. Thus, the Manigaults' Philadelphia friends saw them as fellow aristocrats, not as slaveholding pariahs. Indeed, the abolitionist Benjamin Rush was the family's doctor and close friend.

Rush and other leading Philadelphians recognized Alice Izard and Margaret Manigault as social leaders. Upper-class women, it was understood, were not restricted merely to the exercise of domestic "influence." Although subordinate to men, they were invested with real power within social circles. Cynthia Kierner writes that "genteel culture [in the colonial era] served the interests of patriarchy and of elite dominance, but, as members of the ruling class, women also benefited from its ascendancy." Part of the larger significance to be gleaned from the Manigault women and their circle is that Kierner's conclusions deserve to be extended in both time and space, integrating the early republic (at least) as well as northern and southern gentlewomen into the sphere of feminine elitism. At stake on Spruce Street's salons was not just the survival of privilege in the new nation, but the maintenance of a truly "American" leisure-class identity. ${ }^{5}$

Such an understanding helps explain the preference of these planting women for Philadelphia, the most urbane city in early national America. Indeed, considering Alice Izard's lineage - she was born Alice De Lancey, after all-her choice of Philadelphia takes on heightened significance. Like their fellows in the tidewater aristocracy of Georgia and South Carolina, the Manigaults and Izards preferred the glittering world of the eastern commercial ports to life on their rice and cotton plantations. Lowcountry squires, wrote Harriott Ravenel, were "as much town folk as country gentlemen." And though the importance of Charleston in the cultural life of South Carolina has been well established, less well understood is that planters were seldom satisfied to play exclusively upon this rather parochial stage. They sought their place in the national

5 Cynthia Kierner, "Hospitality, Sociability, and Gender in the Southern Colonies," Journal of Southern History, 62 (Aug. 1996), 450. 
aristocracy, a class at home that for all Charleston's allurements failed to measure up to their cosmopolitan standard. ${ }^{6}$

In the young nation, Philadelphia, and only later New York, ranked as centers of refinement. To be sure, bourgeois Boston and tiny Charleston had their champions, but neither could offer the combination of size, sociability, and variety of the two commercial giants. The upper ranks of Boston, as Ronald Story has shown, remained closely identified with its region's distinctive religious and intellectual traditions. Well after being surpassed by New York City later in the century, Philadelphia remained the cultural capital, especially for those of a conservative, antidemocratic stripe. Some European visitors ratified Philadelphians' aristocratic selfimage. "The Philadelphians claim being the first in rank in society of any town in the States," wrote Margaret Hall the day after an 1827 ball, "and the specimen of last night makes good the pretension." Because European visitors were such an ubiquitous presence at Philadelphia social affairs, the display of sophistication took on a heightened significance. The point was not to emulate continental manners. As David Shields points out, "[t]asteless persons could always mimic the dress and gestures of gentlepersons." American hostesses displayed the accomplishments and conversation of their guests to show how they had constructed a new kind of gentility, refined yet purged of aristocratic excess. ${ }^{7}$

Besides claiming to be the center of cultivation, Philadelphia had other merits that made it attractive to southerners. In 1781, following the capture

${ }^{6}$ Harriot Horry Ravenel, Charleston: The Place and the People (New York, 1906), 385. On Charleston society, see George C. Rogers, Jr., Charleston in the Age of the Pinckneys (Norman, 1969); Michael Johnson, "Planters and Patriarchy: Charleston, 18001860," Journal of Southern History, 46 (Feb. 1980), 45-72; and Michael O'Brien and David Moltke-Hansen, eds., Intellectual Life in Antebellum Charleston (Knoxville, 1986). On ties between North and South, particularly urban connections, see Edward Pessen, "How Different from Each Other Were the Antebellum North and South?" American Historical Review, 85 (Dec. 1980), 1119-49; David R. Goldfield, Urban Growth in the Age of Sectionalism: Virginia, 1847-1861 (Baton Rouge, 1977); Harriet B. Amos, Cotton City: Urban Development in Antebellum Mobile (University, AL, 1985); Iver Bernstein, The New York City Draft Riots: Their Significance for American Society and Politics in the Age of the Civil War (New York, 1991); and Steven M. Stowe, Intimacy and Power in the Old South: Ritual in the Lives of the Planters (Baltimore, 1987).

${ }^{7}$ Mrs. Basil Hall [Margaret Hunter Hall], The Aristocratic Journey: Being the Outspoken Letters of Mrs. Basil Hall Written During a Fourteen Months' Sojourn in America, 1827-1828, ed. Una Pope-Hennessy (New York, 1931), 139; Shields, Civil Tongues and Polite Letters, 39; Ronald Story, "Class and Culture in Boston: The Athenaeum, 1807-1860," American Quarterly, 27 (May 1975), 178-99; Story, The Forging of an Aristocracy: Harvard and the Boston Upper Class, 1800-1870 (Middletown, CT, 1985). 
of Charlestown and the imprisonment of revolutionary leaders, the British exiled five hundred and seventy patriots to Philadelphia. ${ }^{8}$ Among the Carolinians present there either as exiles or members of Congress were Ralph Izard, Arthur Middleton, Thomas Pinckney, and John Rutledge, all of whom retained links of business and friendship to the city after independence. During the years in which Philadelphia served as the seat of the national government these ties grew stronger. Later, being the closest major city to the national capital, Philadelphia became the residence of many among the European diplomatic corps. These genteel foreigners "had not ceased to consider Philadelphia the social Capital of the Country," noted one gentleman, and their presence made the city even more attractive to socialites. Finally, despite its significant population of antislavery Quakers, and the founding of the American Anti-Slavery Society there in 1833 , the city's upper crust was actually quite prosouthern and conservative throughout the antebellum era. Charles Godfrey Leland, who grew up in Philadelphia, remembered that "everything southern was exalted and worshiped" in his home town. ${ }^{9}$

8 On the South Carolina exiles, see David Duncan Wallace, The History of South Carolina (4 vols., New York, 1934), II, 227; and Malcolm Bell, Jr., Major Butler's Legacy: Four Generations of a Slaveowning Family (Athens, GA, 1982), 37. Not all observers witnessed amicability between Pennsylvanians and their southern guests. George Grieve reminisced that "such was the cold, selfish spirit of too many of the inhabitants of Philadelphia towards their Carolina brethren, who had every claim upon their sympathy and good offices, as to merit the indignation of every feeling mind, and to fix an indelible stain upon their character as men and citizens." Grieve contradicted the view put forth by the Marquis de Chastellux in the notes of his translation of the Frenchman's travels. François Jean Chastellux, Travels in North America in the Years 1780, 1781, and 1782, ed. Howard C. Rice, Jr. (2 vols., Chapel Hill, 1963), II, 593. Mabel Webber, ed., "Josiah Smith's Diary, 1780-1781," South Carolina Historical Magazine, 34 (Winter 1932-33), 67-210, a firstperson account of an exile, stresses the fellowship between Philadelphia and Charleston patriots.

9 "Recollections of Joshua Francis Fisher," J. Francis Fisher Section, Cadwalader Collection (Historical Society of Pennsylvania, Philadelphia); Charles Godfrey Leland, Memoirs (New York, 1896), 136. On Philadelphia's ties to the South, see Elizabeth Geffen, Philadelphia Unitarianism, 1786-1861 (Philadelphia, 1961); Bell, Major Butler's Legacy; Stowe, Intimacy and Power in the Old South; Daniel Kilbride, "Philadelphia and the Southern Elite: Class, Kinship, and Culture in Antebellum America" (Ph.D. diss., University of Florida, 1997); An Antebellum Plantation Household: Including the South Carolina Low Country Receipts and Remedies of Emily Wharton Sinkler, ed. Anne Sinkler Whaley LeClerq (Columbia, SC, 1996); and George Washington's Beautiful Nelly: The Letters of Eleanor Parke Custis Lewis and Elizabeth Bordley Gibson, 1794-1851, ed. Patricia Brady (Columbia, 1991). Also see Richard G. Miller, "The Federal City, 1783-1800," in Russell F. Weigley, ed., Philadelphia: A 300-Year History (New York, 1982), 155-205; Ethel E. Rasmusson, "Democratic Environment-Aristocratic Aspiration," Pennsylvania Magazine 
Though Philadelphia's prosouthern attitude made it a congenial city, southern ladies and gentlemen went there mostly to consort with others of similar habits and tastes. This is not to say that they accepted "northern" standards of merit. Rather, northern and southern bluebloods subscribed to a cosmopolitan criterion of excellence. Wealth and sophistication distinguished them from ordinary people everywhere. Mary Huger Middleton expressed this urbanity perfectly when, on a grueling trip through the upcountry, she wrote to her friend Margaret Manigault, comfortable in her summer home on the Delaware. She found little in common with the rough women she encountered in the piney woods, fellow southerners though they were. "In these parts all that [is] necessary for a woman to know was the curing of bacon \& making soap. You will allow," Middleton complained to her friend in the North, "that those accomplishments are incompatible with studying Montaigne."10

Relocating to Philadelphia was thus both a practical decision-wealthy Carolinians typically abandoned their stifling estates in the summertime for more temperate climes-and a cultural statement. Margaret Manigault, her son recalled, had "become a stranger [from the South] ... from her long absence in Europe." And because they found New York "bleak and blustering, with a constant crowd in all the principal streets," that city was "not a place to suit our family as a residence winter or summer." In 1807, Gabriel Manigault purchased Clifton, a rural seat overlooking the Delaware in Bristol, from fellow Carolinian Wade Hampton. "Clifton," reminisced Joshua Francis Fisher, "was a very large house, with rooms, I remember, of palatial proportions" that could accommodate the large numbers of Philadelphia and Carolina friends the Manigaults received. Gabriel's mother-in-law continued to rent a townhouse in the winters while spending her summers at her son George's nearby estate, where she supervised the education and social lives of the circle's young women. These permanent residences freed distant family and friends from patronizing expensive and impersonal boarding houses. On their way to the northern springs, southern travelers sojourned at Clifton, where they might mingle with Philadelphians at their adjacent country houses. These were much more than family retreats. As centers of social activity, they attracted local families on social calls as well as faraway travelers. And as sites for balls,

of History and Biography, 90 (Apr. 1966), 155-82; and Rufus Wilmont Griswold, The Republican Court: or, American Society in the Days of Washington (New York, 1856), for Philadelphia society in the 1790 s.

${ }^{10}$ Mary Huger Middleton to Margaret Manigault, n.d., Cadwalader Collection. 
supper parties, and salons, they served as arenas for cultural exchange and class cohesion. ${ }^{11}$

Gabriel and Margaret Manigault enjoyed the beau monde, but their frequent travels made the establishment of a permanent "colony" in the North untenable. However, an unexpected tragedy, Gabriel's sudden death in 1809 , made such a move not only possible but psychologically and logistically imperative. Alice Izard and Margaret Manigault, as widows with young children, required each other's support. Although the Bristol house sufficed for the summer months, it was too far from the city to serve the family during the busy winter social season, when bad weather might prevent trips to town or visits with neighbors. Margaret rented a small townhouse on Spruce Street through the 1810s, though it proved inadequate to hold the large family comfortably. Alice encouraged her daughter to find a more spacious residence from which they could supervise the debuts of the young women of the family and host larger entertainments. She should "be very glad ... to put myself entirely under your auspices," she prodded Margaret in 1816, but only "as soon as you have a town house large enough to contain us all conveniently."

There can be no doubt that Gabriel's death was a hard blow for Margaret: like her mother's marriage to Ralph Izard, theirs was a close match. Nor can it be denied, however, that her husband's untimely demise provided the strong-willed widow with opportunities. As Lee Virginia Chambers-Schiller and Anya Jabour have shown, young women at this time often favored spinsterhood- - single blessedness"-if they could not secure

11 Charles Manigault, "Some Things Relating to Our Family Affairs," Charles Manigault Papers, Southern Historical Collection (Wilson Library, University of North Carolina, Chapel Hill). (I am indebted to Angie Tacker for this citation.); "Recollections of Joshua Francis Fisher," Cadwalader Collection. On northern vacations see Lawrence Fay Brewster, Summer Migrations and Resorts of South Carolina Low Country Planters (Durham, 1947). On Clifton and the resort community see Marion Willis Rivinus and Katherine Hansell Biddle, Lights Along the Delaware (Philadelphia, [1965]), 65-67; S.F. Hotchkin, The Bristol Pike (Philadelphia, 1893), 343-44; Carl Bridenbaugh, "Baths and Watering Places of Colonial America," William and Mary Quarterly, 3 (Apr. 1946), 151-81; and F.H. Shelton, "Springs and Spas of Old-Time Philadelphians," Pennsylvania Magazine of History and Biography, 47 (July 1923), 196-237. On Bristol/Philadelphia society see Betty-Bright P. Low, "On Muslins and Merveilleuses: Excerpts from the Letters of Josephine du Pont and Margaret Manigault," Winterthur Portfolio, 9 (1974), 29-75; and esp. Low, "The Youth of 1812: More Excerpts from the Letters of Josephine du Pont and Margaret Manigault," ibid., 11 (1976), 195.

12 Alice Izard to Margaret Manigault, Mar. 14, 1816, Manigault Family Papers. 


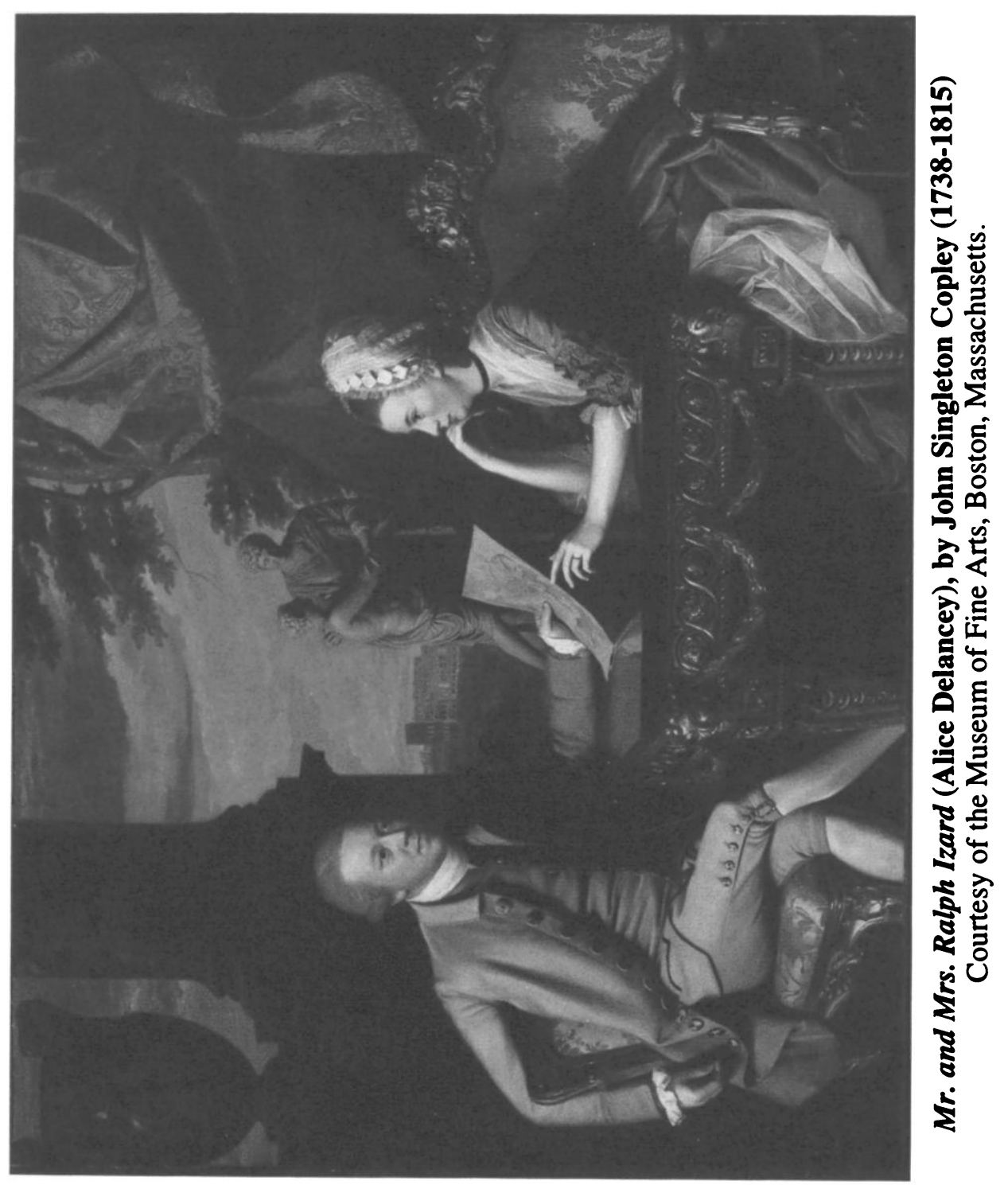


"conjugal bliss in a truly companionate marriage."13 In a sense, Margaret and her mother had the best of both worlds. Now free of male control and, just as significant, left with the means to act on that freedom, Margaret Manigault moved decisively to shape the future course of her family. In 1816 she purchased a large house at Eighth and Spruce Streets, near the heart of Philadelphia's fashionable district. Boasting "a Mansard roof" and all the "ingredients in the composition of Comfort \& well being," the residence could house family and friends with ample room to entertain. Soon after, her brother, mother, and two sisters moved onto the same block. To Philadelphians, this stretch of Spruce Street became the "Carolina Row." In the salons on Spruce Street, and in similar places such as Newport and Saratoga, the early national gentry maintained the sensibility that their privileged economic status reflected genuine social and cultural superiority. ${ }^{14}$

Social visits and salons were primary sites where the Manigault women sought to embody and assert the merits of privilege. Both activities straddled the increasingly fuzzy line between public and private activity. The distinction between public and private behavior conventionally has been associated with political and nonpolitical action, respectively, which helps explain why the trope has come under considerable criticism in recent years in a variety of fields. The distinction is hardly meaningless, however. Polite visits and, to a lesser extent, social galas remained largely selfcontained, intimate affairs between small groups of friends and families. Many of the functions of the social call-exchanging news and gossip, displaying fashions, and shopping, for example-were hardly political acts. Yet even these substantially "social" behaviors communicated messages

${ }^{13}$ Lee Virginia Chambers-Schiller, Liberty, A Better Husband: Single Women in America: The Generations of 1780-1840 (New Haven, 1984); Anya Jabour, "'It Will Never Do for Me to Be Married': The Life of Laura Wirt Randall, 1803-1833," Journal of the Early Republic, 17 (Summer 1997), 217. On single women in the South, see also Michael O'Brien, ed., An Evening When Alone: Four Journals of Single Women in the South, 18271867 (Charlottesville, 1993); and the letters of Mary Telfair, a Savannah spinster, in Joan Cashin, ed., Our Common Affairs: Texts from Women in the Old South (Baltimore, 1996).

${ }_{14}$ Margaret Manigault to Gabriel Henry Manigault, Mar. 16, 1818, Louis Manigault Papers (Special Collections Library, Duke University, Durham); "Recollections of Joshua Francis Fisher," Cadwalader Collection; Alice Izard to Margaret Manigault, Mar. 14, 1816, Manigault Family Papers. In Susan Petignu King, Gerald Gray's Wife; and, Lily: A Novel, ed. Jane H. Pease and William R. Pease (1855; rep., Durham, 1993), 74, Alicia Barclay informs the heroine, both students at a Philadelphia ladies' academy, that the houses they are passing "were called Carolina Row ... such numbers of our country people occupied and owned them." King, daughter of Palmetto State jurist James Louis Petigru, attended Madame Guillon's academy in Philadelphia in the 1820s. 
about status and power. The exercise of the latter, Lynn Hunt has written, "always requires symbolic practices." 15

As ordinary people challenged the gentry's control over the terms of refinement and cultivation, visiting and walking became more private acts for the gentry. They changed from public performances designed to impress upon the lower orders the wealth and cultivation of the gentry, to private, but no less political, rituals designed to reinforce upper-class cohesion by cementing personal bonds and maintaining cultivated manners. Display was an important element of social visiting in the colonial era, as Richard Bushman has shown. On the idealized eighteenth-century promenade, "a lady could properly show herself and ... the surroundings harmonized with the manners." By the nineteenth century, however, the "most constant source of irritation for the genteel population was urban street life." Refined folk retreated into private, controlled spaces such as parks, exclusive neighborhoods, and their own parlors. ${ }^{16}$

The gentry's retreat into private venues mirrored changes in Federalist political culture in the early years of the nineteenth century. Indeed, they grew out of the same impulses. As David Waldstreicher, Len Travers, and Albrecht Koschnik have shown, Federalists responded to their 1800 defeat by withdrawing from public patriotic celebrations because they viewed themselves as the only true guardians of the revolutionary legacy. "From the Federalist perspective," argues Koschnik, "the Fourth of July celebration no longer constituted an appropriate expression of "Americanism."' This rather petulant response failed to satisfy some younger Federalists, who formed new organizations to embody the "principles of Washington's government"; but they too left the public stage by 1815 . These new societies, including the Sons of Washington and the Washington Benevolent Society, did not abandon politics when they retreated into the private sphere: instead, they kept alive the elitist spirit as an explicit counterpoint to leveling trends in popular political culture. Similarly, women's visiting and walking patterns no longer served to impress social inferiors but operated to sustain aristocratic ideals within the select group itself. ${ }^{17}$

${ }^{15}$ Lynn Hunt, Politics, Culture, and Class in the French Revolution (Berkeley, 1984), 54. There are many works on the public-private distinction. See Jeff Weintraub, "The Theory and Politics of the Public/Private Distinction," in Jeff Weintraub and Krishan Kumar, eds., Public and Private in Thought and Practice: Perspectives on a Grand Dichotomy (Chicago, 1997), 1-42. Rising."

${ }^{16}$ Bushman, The Refinement of America, 165, 368. See also Hemphill, "Middle Class

${ }_{17}$ Waldstreicher, In the Midst of Perpetual Fetes, 85-107, 187-93; Koschnik, "Rituals of National Celebration," 244. 
Like other gentlefolk, the Manigault women felt keenly the ineffectiveness of public displays of their wealth and sophistication in the postrevolutionary era. Social inferiors heaped derision on them in public places-a shocking and overt sign of the erosion of deference. Alice Izard characterized the Jeffersonian era as one of "riotous, boisterous manners." True gentlefolk, her daughter concurred, "grow more and more rare-I very much fear the breed will be lost." Margaret's young daughter Harriet knew that walking the streets was supposed to reinforce class distinctions but expressed frustration that the lower sorts would not cooperate. Common folk encountering genteel women traveling "without a gentleman in the country ... were very apt to be rude," she recorded in her diary. The possibilities for unpleasant encounters multiplied in the city. Bluebloods preferred to control the circumstances of encounters with their subordinates. In regulated environments they minimized the risk of being mocked by those who should have offered them deference. ${ }^{18}$

Like the Federalist men who felt compelled to cancel Fourth of July celebrations after Adams's defeat in 1800, the Manigaults felt betrayed by the changed circumstances of social calling. Republicans were not merely a competing faction; they were a social blight, representing parochialism, vulgarity, and social disorder. "[W]e only want a proper spirit in public affairs," Alice Izard reflected in 1808, "to shew that we are not a little, mean, despicable people." Gentlefolk like Izard saw their privileged status in terms of the reciprocal obligations that held any functioning society together. In exchange for their wealth and talents, a republican aristocracy contributed disinterested leaders of public opinion, producers and patrons of high culture, and examples of true refinement to the lower sorts. American aristocrats were simply befuddled that the lower orders refused to recognize their betters' good intentions. Robert Waln, whose Philadelphia family was close to the Manigaults, was provoked by the ridicule he and other bluebloods endured on the city's streets to pen a spirited defense of privilege. "[I]n all civilised societies, an aristocracy must and will exist," insisted the young Quaker merchant. "[T]he power thus enjoyed by blood, by riches, and by learning, is as extensively exercised, and produces as great an effect over the minds of the lower orders of people." His appeal fell on deaf ears. The derision, hostility, and even violence leveled at the Manigaults and other elite families formed part of a larger revolt against authority during which, Gordon Wood maintains, "common ordinary men

18 Alice Izard to Margaret Manigault, Mar. 31, 1811, Manigault to Izard, July 12, 1812, Manigault Family Papers; Harriet Manigault Diary, July 31, 1814 (Historical Society of Pennsylvania, Philadelphia). 
stripped the northern gentry of their pretensions, charged them at every turn with being fakes and shams, and relentlessly undermined their capacity to rule." 19

If polite visits were fast losing their social significance to the less privileged, they remained a significant tool in maintaining class cohesion. Karen Hansen has shown how working-class New Englanders invested the social call with their own values. The cementing of personal bonds and the exchange of gossip during polite visits anchored the political consciousness of lower-class Yankees and cosmopolitan patricians alike. In restricting their circle to those who spoke their "language of class," genteel Americans grounded their political beliefs in personal associations. Aristocrats continued to take part in public rituals marking their taste and elevation, though the performances were increasingly directed toward their own set and only tangentially designed to impress their majesty upon the wider community. ${ }^{20}$ They remained fundamental to the transmission and reinforcement of upper-class identity within the elite itself, however. Callers were acutely aware that they were taking part in a sort of theater, their clothing and comportment scrutinized by others poised to ratify or reject their claims to status. Acceptance into elegant parlors conferred elegance upon the visitor. Even for those well established within the upper crust, to be welcomed into the homes of peers affirmed one's position. Alice Izard, no social outcast, expressed delight at her daughter's "having visited Mrs. Shippen \& having been so cordially received by the Dr." Such a reception by one of Philadelphia's most prestigious houses confirmed the honor of the Carolina clan. ${ }^{21}$

19 Alice Izard to Margaret Manigault, Dec. 7, 1808, Mangault Family Papers; Peter Atall [Robert Waln, Jr.], The Hermit in Philadelphia, Second Series. Containing some Account of Young Belles and Coquettes... (Philadelphia, 1821), 80; Wood, Radicalism of the American Revolution, 276. On Waln, see William S. Hastings, "Robert Waln, Jr.: Quaker Satirist and Historian," Pennsylvania Magazine of History and Biography, 76 (Jan./Apr. 1952), 71-80. Waln's works aped the popular Hermit in London, which skewered the pretensions of the British aristocracy.

${ }^{20}$ Asa Briggs, "The Language of 'Class' in Early Nineteenth-Century England," in Briggs and John Saville, eds., Essays in Labor History (London, UK, 1960), 43-73. See also Gareth Stedman Jones, Languages of Class: Studies in English Working Class History, 1832-1982 (Cambridge, UK, 1983); Blumin, Emergence of the Middle Class, 240- $\rightarrow$ Karen V. Hansen, "The Power of Talk in Antebellum New England," Agricultural History, 67 (Spring 1993), 43-64; and Hansen, A Very Social Time: Crafting Community in Antebellum New England (Berkeley, 1994).

${ }_{21}$ Alice Izard to Margaret Manigault, Mar. 9, 1808, Manigault Family Papers. George Izard, son of Alice and brother of Margaret, married Elizabeth Carter Farley, widow of Thomas Lee Shippen of the prominent Philadelphia clan. See Randolph Shipley Klein, 
Most visits were informal social exchanges between women. Men took part in the practice, of course, but most considered it a tedious business. Gabriel Manigault empathized with his son's reluctance to engage in the dull routine, but, he admonished, the social call was "a matter of real consequence in society, \& one on which a young man's character in the world often depends." Harry's father knew that, for the elite, visiting did important cultural work. In contrast to most men, women devoted themselves to the rites of private visiting. Social calls ratified their place in the social scale while providing a forum for the exchange of news and conversation. Walking and visiting enabled women to keep up with current styles by comparing dress, hairstyles, and other fashions. So strong was the class imperative to both see and be seen that even Alice Izard, "so agreeably situated" at her son's estate near Clifton "that I have not a wish to go into any other house," resolved to "conform to the customs, \& manners of the family I am with." To indulge in her "own wishes [to stay at home might] oblige them to break thro' rules of society ... which alto' a trifling sacrifice in the first instance might be attended with disagreeable consequences.",22

Alice's granddaughter Harriet used the polite call as a kind of social scoreboard. Brought up with a strict understanding of the moral value of gentility, she could be harsh with those who failed to meet her exacting standards. After one visit she described the disappointment of her Carolina relatives with Miss Keene, a Philadelphia friend "who I must tell you is very much altered, she has quite a haggard look." The unfortunate lady, who was perhaps just having a bad day, on another instance ranked better than another belle, "the manners of [Keene] so modest \& unassuming, and so much like a lady in every respect, and the other so made up \& conceited." For women of the leisure class, the social call was a point of access to cultivated companions, social convention, and aristocratic competition. $^{23}$

Portrait of an Early American Family: The Shippens of Pennsylvania across Five Generations (Philadelphia, 1975). On how public display before the Revolution served to impress the grandeur and power of the gentry upon the common sorts, see Rhys Isaac, The Transformation of Virginia, 1740-1790 (Chapel Hill, 1982), esp. 43-57.

${ }^{22}$ Gabriel Manigault to Gabriel Henry Manigault, Dec. 9, 1808, Louis Manigault Papers; Alice Izard to Margaret Manigault, Aug. 20, 1805, Manigault Family Papers.

${ }^{23}$ Harriet Manigault to Elizabeth (Manigault) Morris, Aug. 4, 1815, Manigault Family Papers; Harriet Manigault Diary, July 31, 1814. For a contrasting picture to the tone of female gossip presented here, see Carroll Smith-Rosenberg, "The Female World of Love and Ritual: Relations between Women in Nineteenth-Century America," Signs, 1 (Autumn 1975), 1-29. Miss Keene was perhaps the daughter of John Keen, once a vice-president of 
The exchange of polite visits was especially important for travelers. As Hansen points out, social calls cemented friendships which, in turn, grounded political identity. Not only did rounds of visiting reintegrate outof-town visitors into the routines of genteel life, but they served as a personal basis for common conservative sensibility. To put it another way, the memory of personal greeting, conversation, and the exchange of confidences-later cemented by correspondence-created a national aristocratic network. The Carolina Row was only a particularly wellknown manifestation of a nationwide phenomenon. Planters welcomed travelers on the long overland trip from the springs to the Carolinas and other points south, rekindling old acquaintances and keeping up with news and gossip from far away. Virginian Eleanor Parke Lewis reopened a sealed letter to tell her Philadelphia friend Elizabeth Bordley that she "just had a kind visit from" a Carolina friend on the way to the lowcountry from the Quaker city. Lewis returned the favor upon touring Philadelphia years later, when she engaged in the "agreeable amusement of morning visits." Her intimacy with Bordley, a member of the Carolina circle, quickened her reintegration into the city's social whirl. Such relationships were quite common. Spruce Street became the conduit through which refined Carolinians and other southerners entered fashionable life in Philadelphia. Through the routines of small talk, politeness, music, and games emerged the web of intimacy and interest that consolidated a new generation of the Atlantic aristocracy. ${ }^{24}$

If household visits were the everyday way in which wealthy Americans maintained class bonds, salons sought to reinforce eighteenth-century standards of intellectual and social graces within the elite. The Manigault salon was very much a catholic affair, much different from the eighteenthcentury affairs of Elizabeth Magawley in Boston and Anne Willing Bingham in Philadelphia which, David S. Shields argues, "made the cultivation of sense the overriding concern in the conversation of mixed company." Dena Goodman has shown how the salon, an institution regulated and defined by women, had given French women a degree of behind-the-scenes authority in political affairs. Shields suggests that the Gallic salon had to be modified to conform to Anglo-American conditions since "[r]eason and law," the foundations of British colonial society, "were threatened by the personal power exerted by charming women." In fact, the Manigaults had little difficulty attracting men of cultivation and affairs

the Carpenter's Company. See Low, "Youth of 1812," 193.

${ }_{24}$ Eleanor Parke Custis to Elizabeth Bordley, July 2, 1797, and Custis to Bordley, n.d., Eleanor Parke (Custis) Lewis Papers (Historical Society of Pennsylvania, Philadelphia). 
into their parlors. Their soirees combined refined conversation with continental gaiety. Educated in France while her patriot father Ralph Izard served on the American diplomatic legation during the Revolution, Margaret and her mother became certified Francophiles. Whether in Charleston, at Clifton, or on Spruce Street, their salons exhibited none of the stuffiness and exaggerated decorum that European travelers of the 1820 s and 1830s discerned in American affairs. ${ }^{25}$

Indeed, these sociability rituals carried on a colonial tradition of elite women's public action in the service of gentility and upper-class authority. Such behavior contradicted an emerging discourse of gender and power which identified public action with manly virtues. As Cynthia Kierner shows in her study of gender and colonial and early national southern civic rituals, prerevolutionary affairs "explicitly afforded elite women public influence, if not political power. ... [y]et postrevolutionary civic rituals, which promoted a masculine and militarized ideal of citizenship, relegated women of all classes to the fringes of public life."26 Though Kierner limits her analysis to southerners, much the same could be said for women of privilege throughout the postrevolutionary era. The Manigault salon also contradicted the emerging "cult of domesticity," which while inchoate in the early years of the century and exerting only imperfect authority when most influential in the 1830s and 1840s, still circumscribed women's public activity. ${ }^{27}$

${ }^{25}$ Shields, Civil Tongues and Polite Letters, 120; Wendy A. Nicholson, "Making the Private Public: Anne Willing Bingham's Role as a Leader of Philadelphia's Social Elite in the Eighteenth Century" (M.A. Thesis, University of Delaware, 1988); Dena Goodman, The Republic of Letters: A Cultural History of the French Enlightenment (Ithaca, 1994).

${ }^{26}$ Cynthia A. Kierner, "Genteel Balls and Republican Parades: Gender and Early Southern Civic Rituals, 1677-1826," Virginia Magazine of History and Biography, 104 (Spring 1996), 186. A similar point is made by Richard L. Bushman, "American High-Style and Vernacular Cultures," in Jack P. Greene and J.R. Pole, eds., Colonial British America: Essays in the New History of the Early Modern Era (Baltimore, 1984), 345-83.

${ }_{27}$ Feminist critics have pointed out that domestic ideologies never completely sever women from the public world, though they help ensure that women engage themselves publicly in a manner distinctive from men. Jürgen Habermas, The Structural Transformation of the Public Sphere; An Inquiry into a Category of Bourgeois Society, trans. Thomas Burger (1962; rep., Cambridge, MA, 1991), esp. 89-102. Critiques of the public-private distinction abound. See especially Dorothy O. Helly and Susan Reverby, Gendered Domains: Rethinking Public and Private in Women's History (Ithaca, 1992); and Kathy Peiss, "Going Public: Women in Nineteenth-Century Cultural History," American Literary History, 3 (Winter 1991), 817-28. For a review of this debate see, Carole Pateman, "Feminist Critiques of the Public/Private Dichotomy," in Pateman, The Disorder of Women: Democracy, Feminism, and Political Theory (Cambridge, UK, 1989). 
Besides, the domestic creed was an explicitly middle-class construct that, as both Richard Bushman and Stuart Blumin suggest, "respectable" sorts fashioned largely in opposition to an upper-class code they found immoral and anachronistic. Elite women of the early republic assumed they should adopt a limited public role-in the parlor, carriage, ballroom, and fashionable street-to assert the virtues of their class. Such a development had little to do with any liberating influence of the Revolution but emerged from colonial traditions of elite women's public roles. ${ }^{28}$ The Manigaults' salon must be understood within a continuing tradition of conservative women's political activism. Elizabeth Varon has shown how this heritage was carried on by the Whig women of antebellum Virginia. Significantly for the salon tradition, Bertram Wyatt-Brown has described the affairs of Sarah Dorsey, a Philadelphia-educated Louisiana socialite whose intellectually sophisticated salons entertained the Old South's planter elite and who, in the postwar decades, applied her expertise as a hostess to enshrine the "Lost Cause." 29

Thus, class prerogatives virtually compelled the Manigault women to defend the virtues of privilege against what they perceived to be the socially destructive effects of democracy. Under her mother's prodding, Margaret Izard Manigault established a salon in her Spruce Street mansion that maintained principles of elitism and cultivation. Emphasizing both conversation, including political debate, and the exercise of accomplishments such as singing, dancing, and instrumental music, the Carolina Row's salon attracted republican aristocrats-deeply conservative folk committed to republican institutions but disdainful of leveling trends in politics, religion, and culture. The young might be infected with democratic doctrines if they were left to fend for themselves. Though one youth assured Alice Izard he "is a staunch Federalist," she worried he might "be

${ }^{28}$ Blumin, Emergence of the Middle Class, 237; Bushman, Refinement of America, 298-302. Linda K. Kerber, Women of the Republic: Intellect and Ideology in Revolutionary America (Chapel Hill, 1980); Joan Hoff Wilson, "The Illusion of Change: Women and the American Revolution," in Alfred Young, ed., The American Revolution: Explorations in the History of American Radicalism (DeKalb, IL, 1976), 386-431. These works are less sanguine than Mary Beth Norton, Liberty's Daughters: The Revolutionary Experience of American Women (Boston, 1980), on the impact of the Revolution on women's lives. The voluminous literature on women's world in the postrevolutionary era is discussed in Kerber, "Separate Spheres, Female Worlds, Woman's Place: The Rhetoric of Women's History," Journal of American History, 75 (June 1988), 9-39.

${ }^{29}$ Bertram Wyatt-Brown, The House of Percy: Honor, Melancholy, and Imagination in a Southern Family (New York, 1994), 128, 156; Elizabeth R. Varon, "Tippecanoe and the Ladies, Too: White Women and Party Politics in Antebellum Virginia," Journal of American History, 82 (Sept. 1995), 494-521. 


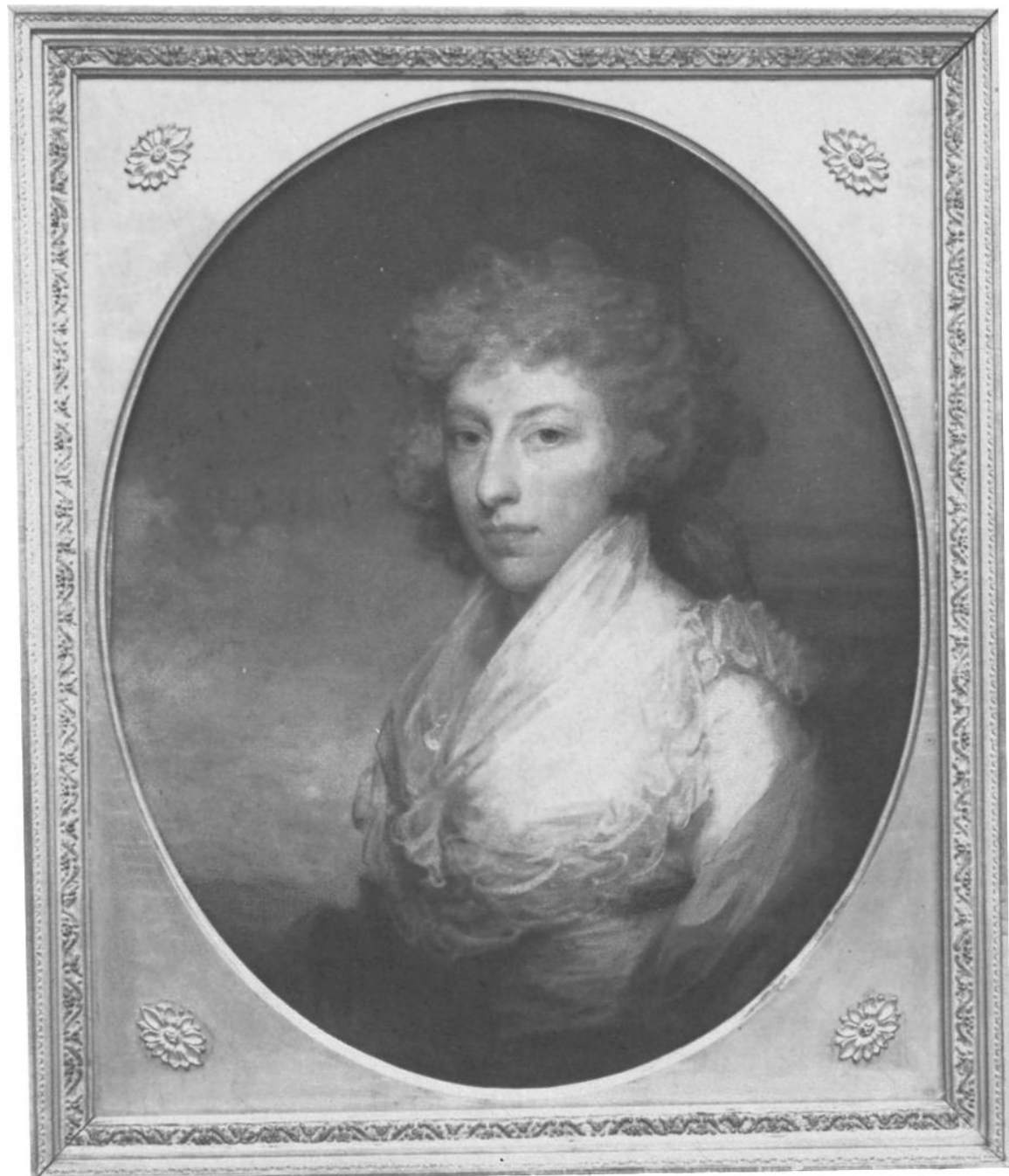

Portrait of Mrs. Gabriel Manigault, by Gilbert Stuart (1742-1786)

Courtesy of the Albright-Knox Gallery, Buffalo, New York. 
induced to change his sentiments by the influence of example." In urging her daughter to raise her children according to old-fashioned standards of gentility, Alice Izard maintained that "our well bred gentlemen must set the example, and so must our well-educated ladies. They are the reformers of the World. To them society has always been indebted for elegance and refinement." Recruiting the young men and women of the family had a twofold purpose. Surrounding the youngsters with a cultivated company would ensure that they grew up with proper values, and so educated they would carry the principles of elitism into the next generation. ${ }^{30}$

Both mother and daughter regarded their enterprise as a public act. Elaborating on gender conventions to advance class interests, they used domestic space for public purposes. The Manigaults distinguished themselves from American hostesses of the eighteenth century by adopting the model of French salonierres, who were more self-consciously political than their English sisters, the bluestockings. ${ }^{31}$ As Alice Izard admonished her daughter in 1811, "[d]o not confine yourself merely to your own circle $\&$ connections. Make your House again pleasant to acquaintances as well as friends \& particularly to Strangers of character." As they saw it, such an action did not so much contradict gender conventions as it emerged from the best traditions of upper-class duty. To retreat to the parlor with close friends and family would constitute a betrayal of the family tradition of public service. Passive conservatism was no longer enough; a leveling age required reactionary action. Margaret had embodied continental sophistication more "than any one in America, \& you must not give it up!" admonished Alice in a reminder of Margaret's past efforts to conserve patrician ways. "It is productive of too much good to be laid aside." 32

As defenders of the patrician faith, the Carolinians would find many sympathetic friends in Philadelphia. Perceiving an encroaching vulgarity in public life, Philadelphia's Federalist community nurtured several creative responses, from Joseph Dennie's "Tuesday Club," a circle of

${ }^{30}$ Alice Izard to Margaret Manigault, Dec. 25, 1808, Izard to Manigault, Mar. 31, 1811, Manigault Family Papers. On colonial and early national society, see Griswold, The Republican Court; Anne Hollingsworth Wharton, Salons Colonial and Republican (Philadelphia, 1900), 118-71; Mrs. [Elizabeth Fries] Ellet, The Queens of American Society (New York, 1867), 135-36; and Anne Marie Dolan, "The Literary Salon in New York, 1830-1860" (Ph.D. diss., Columbia University, 1957). The "salons" discussed by Wharton were little more than polite gatherings having little in common, either in purpose or content, with the salons in Europe or in the Manigaults' homes.

$\ddot{\rightarrow}$ Dena Goodman, "Enlightenment Salons: The Convergence of Female and Philosophic Ambitions," Eighteenth-Century Studies, 22 (Spring 1989), 329-37.

${ }_{32}$ Alice Izard to Margaret Manigault, Mar. 31, 1811, Manigault Family Papers. 
conservative gentlemen identified with the Port Folio, to volunteer militia companies organized during the War of 1812. Members of the Manigault circle took their cue from the atmosphere of intellectual engagement the women encouraged. Joshua Francis Fisher recalled how their "house was the resort of all the intellectual and refined society of our city. ... [ the Manigaults'] taste for literature" attracting "all the educated men and women of the time." Robert Waln, a well-born Philadelphia Quaker of a literary bent penned two genteel satires to expose the "affectations and vanities" that threatened to undermine true gentility in the city. Deriding belles and coquettes, dandies, fops, and gossips, Waln lionized (or invented) "those happy days of primitive simplicity" when, in the gentry's social memory, American society possessed a proper respect for rank. On the face of it, Waln's rendering of a harmonious colonial past reinforces E.P. Thompson's observation that the memories of declining upper orders tend to be more romantic than realistic. Nevertheless, Waln's diagnosis was as harsh as the Manigaults': if society was disintegrating, much of the blame lay with the gentry. If gentlemen acted like schoolboys, and gentlewomen like coquettes, it was no wonder that they were losing respect. The only alternative to extinction was self-discipline and the reassertion of traditional gentry values. ${ }^{33}$

These self-critical, creative responses to republican ascendancy are only now attracting the attention of scholars. They have usually underscored the bitterness and incredulity with which Federalists and other elites responded to their eclipse. ${ }^{34}$ Literature on American salons is not extensive, and much about the Manigaults' affairs can be understood only in terms of their family identity. More generally, though, their salons must be seen as another aspect of a broader elitist response to increasing political and social isolation. Some features of their salons-particularly their combination of intellectually and politically engaged conversation with misleadingly "light" accomplishments like dancing, instrumental music, and cards-were highly distinctive in the Anglo-American context. Other features, however, particularly their politically-charged nature, situate these

33 "Recollections of Joshua Francis Fisher," Cadwalader Collection; Atall, Hermit in Philadelphia, 63-64; Thompson, "Eighteenth-Century English Society," 136-37; Milton Harold Ellis, Joseph Dennie and His Circle: A Study in American Literature (Austin, 1915).

34 A notable exception to this scholarly trend is Fischer, Revolution of American Conservatism, though Fischer concentrated on conventional political responses. For new approaches, see Waldstreicher, In the Midst of Perpetual Fetes, esp. 206-16; and Koschnik, "Political Conflict and Public Contest." On Federalist-elite bitterness, see Joseph J. Ellis, After the Revolution: Profiles of Early American Culture (New York, 1979), 73-110; and Wood, Radicalism of the American Revolution, 267. 
salons alongside other Federalist civic rituals such as Washington's birthday balls, Fourth of July celebrations, and other exclusive affairs. As members of the South Carolina Federalist establishment, the Manigaults had taken part in exclusive party rituals with other prominent families, particularly the Pinckneys. After their defeat in 1800, the Manigaults withdrew from republican-led civic celebrations they viewed as distasteful and illegitimate. Like some other Federalists, they remained committed to elitist political and social styles, though their salon ought to be understood as a particularly creative and contentious expression of leisure-class resistance and self-renewal. ${ }^{35}$

As Joshua Francs Fisher recalled, much of the attraction of the Carolina Row's salons lay in the intellectual qualities of the family itself, particularly its women. Though distinguished from continental salons by their variety, wit and disputation played a major part in these affairs. As scholars have begun to question the contemporary relevance of historical constructs such as republican motherhood and the domestic sphere, they have started to uncover the extent of women's intellectual engagement in the early national period. The students at the Young Ladies' Academy of Philadelphia, notes Margaret A. Nash, "did not rhapsodize about education preparing them for a desired future as republican mothers and wives." The intellectual engagement of certain prominent women, particularly Abigail Adams, has long been appreciated. Less renowned women, historians have begun to discover, also prized the life of the mind, though they also tended to be either privileged or socially ambitious. Laura Wirt Randall, for example, developed a "commitment to intellectual development on her own terms" that contributed to a desire to seek a life of "single blessedness," though she did eventually marry. What must be emphasized is that this tradition of public engagement by women was largely an upper-class, conservative affair. Imperfect as they were in practice, the principles of republican motherhood and, later, true womanhood did constrain women's participation in the public sphere. Conservatives had less difficulty than those of a democratic bent in recognizing women's participation in the polity. Not rhetorically committed to equality to begin with, the gentry did not believe that women's actions contradicted their elitist worldview.

35 Wharton, Salons Colonial and Republican; Ellis, Joseph Dennie and His Circle; Dolan, "The Literary Salon in New York," Peter Quennell, Affairs of the Mind: The Salon in Europe and America from the 18th to the 20th Century (Washington, DC, 1980); Shields, Civil Tongues and Polite Letters; Nicholson, "Making the Private Public." 
Besides, as the Manigault circle demonstrated, gentlewomen could be articulate and forceful defenders of privilege. ${ }^{36}$

The Manigault women received only encouragement from the men in their circle in cultivating their minds, and they eagerly sought out women of similar temperament. Residence in Philadelphia, of course, made this a relatively easy task. Upon hearing from Robert Walsh that Madame de Kantzow-whom Margaret characterized as "without exception the most accomplished Lady that was ever seen in America"-they eagerly (and successfully) sought out her company, and indeed the families became fast friends. Margaret encouraged her daughters to pursue the life of the mind regardless of social pressures. Noting to her daughter Elizabeth that John Vaughan had just presented her with a gift of "Anna Seward's letters which I desired very much to see," she confided that, like Walpole, she found Seward's "style ... an abominable one." She tried to inculcate a similar spirit of intellectual engagement in her daughter by urging her to subscribe to the Select Reviews, in which she might "find sentiment \& instruction." Not only would they provide entertainment, but "[t]hey tell you what is going on in the Literary world." In assuring her daughter that she was "not afraid of your growing a Blue Stocking," Margaret was encouraging her to cultivate the life of the mind regardless of emerging notions of feminine delicacy, not urging on her the mawkish sentimentality and moral didacticism that became associated with that set. ${ }^{37}$

${ }^{36}$ Margaret A. Nash, "Rethinking Republican Motherhood: Benjamin Rush and the Young Ladies' Academy of Philadelphia," Journal of the Early Republic, 17 (Summer 1997), 187-88; Jabour, "'It Will Never Do For Me to Be Married'," 205. On Adams see, Lynne Withey, Dearest Friend: A Life of Abigail Adams (New York, 1981); and Edith B. Gelles, Portia: The World of Abigail Adams (Bloomington, 1992).

${ }^{37}$ Margaret Manigault to Mrs. Joseph Allen Smith, Dec. 6, 1813, Manigault Family Papers; Margaret Manigault to Elizabeth Manigault Morris, Oct. 28, 1812, ManigaultMorris-Grimball Papers (Southern Historical Collection). Anna Seward, "The Swan of Lichfield," was a poet, biographer, and correspondent of Walter Scott. The collection of literary correspondence read by Manigault was probably Seward, Letters of Anna Seward: Written between the Years 1784 and 1807 (6 vols., Edinburgh, 1811). On women's intellectual and literary interests, see Cathy Davidson, Revolution and the Word: The Rise of the Novel in America (New York, 1986); Susan Phinney Conrad, Perish the Thought: Intellectual Women in Romantic America, 1830-1860 (New York, 1976); and Mary Kelley, "Reading Women/Women Reading: the Making of Learned Women in Antebellum America," Journal of American History, 83 (Sept. 1996), 401-24. Cynthia A. Kierner, "Patrician Womanhood in the Early Republic: The Reminiscences of Janet Livingston Montgomery," New York History, 73 (Oct. 1992), 389-407, gives an account of a woman whose determination and conservative inclinations mirrored that of the Manigaults. On bluestockings see, Shields, Civil Tongues and Polite Letters, 120; and Sylvia Harcstark Myers, The Bluestocking Circle: Women, Friendship, and the Life of the Mind in 
Though the Manigault clan took its intellectual responsibilities seriously, both as the foundation for personal happiness and class leadership, they were dismayed at what they perceived as utilitarian trends in contemporary thought. In later decades, objections to materialistic, mercenary aspects of northern culture would emerge as a staple of southern criticism of that region. At this time, however, planters and their northern peers interpreted these developments less as evidence of sectional divergence than as general cultural degradation. ${ }^{38}$ Not surprisingly, these trends provided the fodder for salon disputations. Aimeé Sigoigne, an exile from San Domingue who would later establish a Philadelphia finishing school popular with southern students, introduced Nicholas Biddle, lately returned from travels in Europe, to the circle. The day's discussion revolved around scientific developments on the continent, particularly those of "[Franz Josef] Gall, a German, \& his ideas on the power of education on the brain." Alice Izard was repulsed by his materialistic notions of thought, motivation, and sensation-what would later be known as phrenology. "How vague are such theories," she admonished. "How little capable of leading to happiness." Their company found the likes of Addison and Steele far more congenial. "Some of these authors of the passed [sic] century were wise, \& clever beings," by far the superiors of the current era, she mused. "The wise ones of the present day have unveiled nature ... they have rendered what was once an innocent, \& delightful amusement, almost a reprehensible one." Seen in this light, the political project of the Carolina Row's salons seems not so much conservative as reactionary. They sought to overturn, or at least contradict, a culture that, to their mind, encouraged skepticism and contempt for authority, particularly in youth. "I sometimes think that it is owing to the young people of our times attending to such discussions that they are so bold, \& indelicate," Alice mused after Biddle's audience. ${ }^{39}$

Eighteenth-Century England (Oxford, UK, 1990).

${ }^{38}$ On southern hostility to these aspects of contemporary thought, see, among other works, Drew Gilpin Faust, A Sacred Circle: The Dilemma of the Intellectual in the Old South, 1840-1860 (1977; rep., Philadelphia, 1986); Michael O'Brien, "The Lineaments of Antebellum Southern Romanticism," in O'Brien, ed., Rethinking the South: Essays in Intellectual History (Baltimore, 1988), 38-56; Daniel Kilbride, "Slavery and Utilitarianism: Thomas Cooper and the Mind of the Old South," Journal of Southern History, 59 (Aug. 1993), 469-86.

${ }_{39}$ Alice Izard to Margaret Manigault, Jan. 29, 1809, Izard to Manigault, Mar. 10, 1811, Manigault Family Papers. On Biddle, see Thomas P. Govan, Nicholas Biddle: Nationalist and Public Banker, 1786-1844 (Chicago, 1959). Franz Josef Gall, On the Functions of the Brain and of Each of its Parts ... . (6 vols; Boston, 1835), was influential among some American men of science. See also the review by Thomas Cooper, "Gall On the Functions 
True to their genteel heritage, these women adored cards, music, and dancing. As salonierres, though, they treasured conversation above all. As David Shields has observed, one difficulty faced by American salonierres from Elizabeth Magawley to the Manigaults "was how to attract men of sense into a space dominated by women." Actually, the problem was less severe than Shields suggests, at least for privileged women in the postrevolutionary era. Because they did not tend to see politics and the public sphere in rigidly masculinized terms, gentlemen were less likely to be offended by women's prominence. Other reasons also suggest themselves. Not only did cultivated men prize the company of refined women - both as potential mates and, in the case of the older men of the circle, as touchstones to times past-but elite men could only agree with the Manigaults' reactionary political designs. Joshua Francis Fisher attended the family's affairs as a young man and, decades later, fondly recalled both their cultivation and conservatism. "Men of wit and science knew where they could always find congenial society of both sexes," he reminisced, noting that the Manigaults attracted those republican aristocrats who had "ardently opposed royal tyranny, without the slightest sympathy with Democracy."11

In writing invitations to their salon, political opinion weighed less than social station, wit, and manners. John Vaughan's friendship guaranteed a steady stream of enlightened "strangers" proficient in science and polite letters. Still, the Manigaults associated closely with the city's Federalist establishment and restricted their circle to only the best families. Their small group of intimate friends included Vaughan, a non-dogmatic Federalist; William Short, Jefferson's former secretary, "adopted son," and Francophile; and José Francisco Correa da Serra, Portuguese diplomat, disillusioned democrat, and friend of the French Revolution. Other American family favorites included Elizabeth [Bordley] Gibson, Isabella Mease (related through marriage to the Butler clan), the Hopkinson family, and whatever eminent Carolinians and Virginians happened to be in town.

of the Brain," Southern Review, 1 (Feb. 1828), 134-59. Cooper lived in Philadelphia at this time and may well have known the Manigaults and Izards. He later became president of South Carolina College.

${ }^{40}$ Shields, Civil Tongues and Polite Letters, 100. On salonierres and discussion, see Joan B. Landes, Women and the Public Sphere in the Age of the French Revolution (Ithaca, 1988); Dena Goodman, "Enlightenment Salons"; and Goodman, The Republic of Letters.

${ }_{41}$ "Recollections of Joshua Francis Fisher," Cadwalader Collection. On the association between masculinity and political culture developing in this era and maturing in the second party system, see Kierner, "Genteel Balls and Republican Parades"; on a later era, Paula Baker, The Moral Frameworks of Public Life: Gender, Politics, and the State in Rural New York, 1870-1930 (New York, 1991), 55. 
Both the company's cultivation and its exclusiveness stood out as explicit counterpoints to Republican-influenced affairs which, as the Virginian Elizabeth Gamble complained, tended to be "crowded with every description of persons." As Republican civic rituals and assemblies reflected their more dynamic, inclusive ideology, Federalists and self-proclaimed aristocrats "sought to perpetuate elitist political" and social forms in a clear defense of the virtues of privilege. ${ }^{42}$

John Vaughan was by far the most beloved and important non-family member of the circle. In this well-placed gentleman-he served successively as the Treasurer and Librarian of the American Philosophical Society from the 1790s until his death in 1841-the Manigaults found a kindred spirit eager to use his contacts in the Anglo-American scientific community to channel interesting guests into their parlors. ${ }^{43}$ His friendships with Henry Laurens, Henry Middleton, Thomas and Charles Cotesworth Pinckney, and adopted Carolinian Thomas Cooper may have dated from his European years, when his family's acquaintance with radicals like Joseph Priestley facilitated contacts with like-minded Americans. Carolina patriots trusted Vaughan as their agent when Philadelphia hosted the national government in the 1790s. Well into the next century, Charleston's sons and daughters were eager to repay his benevolence. "What a great man you are in Charleston!" exclaimed Correa da Serra to Vaughan in 1815. Vaughan assisted well-heeled Carolinians visiting his city, receiving shipments, watching for cheap rents, and even inspecting properties for purchase. Natives noted that Vaughan seemed "particularly intimate with the colony of Carolinians on Spruce Street."

${ }^{42}$ Kierner, "Gender and Southern Civic Rituals," 195. On Correa, see Richard Beale Davis, "The Abbé Correa in America: The Contributions of the Diplomat and Natural Philosopher to the Foundations of our National Life," Transactions of the American Philosophical Society, 45, No. 2 (1955), 87-197; on Short, see George Green Shackelford, Jefferson's Adoptive Son: The Life of William Short, 1759-1848 (Lexington, 1993); on Elizabeth Bordley, see Brady, ed., George Washington's Beautiful Nelly, 1-16.

${ }^{43}$ Born into a liberal English merchant family in 1756, Vaughan emigrated to Philadelphia in 1782. Though there is no published biography of this remarkable and important man, personal information can be found in Geffen, Philadelphia Unitarianism; Craig C. Murray, Benjamin Vaughan (1751-1835): The Life of an Anglo-American Intellectual (New York, 1982); and J.H. Sheppard, "Reminiscences and Genealogy of the Vaughan Family," New England Historical and Genealogical Magazine, 19 (1865), 343-56. Testimonials to his gregarious, benevolent temperament can be found in "Recollections of Joshua Francis Fisher," Cadwalader Collection. See also Life and Writings of Jared Sparks, Comprising Selections from His Journals and Correspondence, ed. Herbert Baxter Adams (New York, 1893); and Life, Journals, and Correspondence of Rev. Manasseh Cutler, LL.D., ed. William Parker Cutler and Julia Perkins Cutler (2 vols., Cincinnati, 1888). 


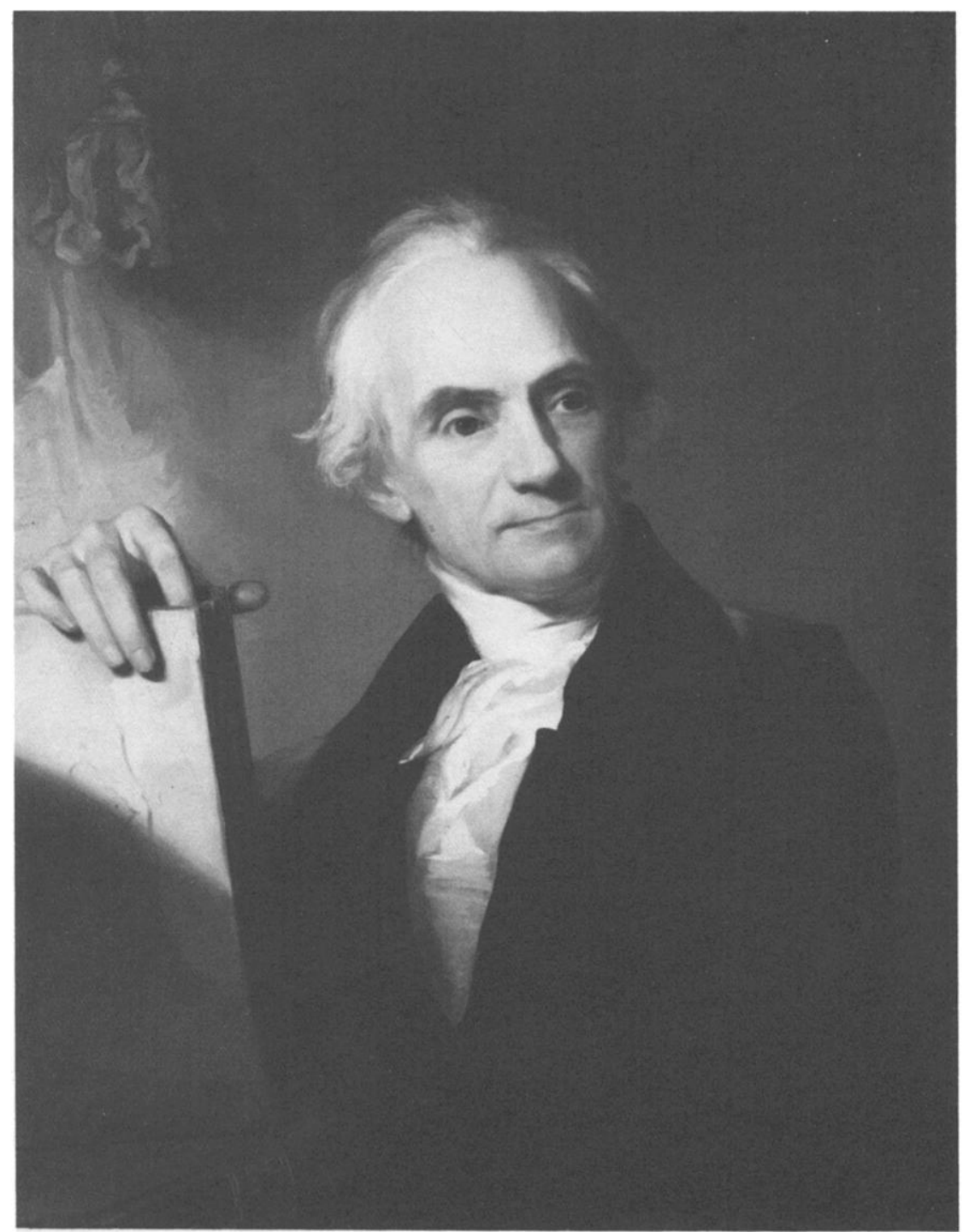

John Vaughan, by Thomas Sully (1783-1872) Courtesy of the American Philosophical Society Library, Philadelphia. 
Indeed, the old Englishman constituted the core of a "society of old gentlemen" that graced the parlors of the Carolina Row on winter evenings well into the 1830 s. Vaughan was certainly an exceptional individual, but he personified the ties of friendship, intellectual interest, and class outlook that bound together the postrevolutionary elite. ${ }^{44}$

Vaughan was just one of a small circle of single, older men with whom the Manigault women associated closely during the first decades of the nineteenth century. Vaughan, William Short, and Correa da Serra, who comported themselves within the traditions of eighteenth-century sociability, were most congenial companions. The controversial Abbé proved a treasured companion to the circle, and especially to Margaret, during his years in America. "The Abbate reasons, \& moralizes with me while my Mother \& three others play at Whist," she recalled with pleasure. More was at stake than pleasant "long winter evenings," however. Their wit, cosmopolitanism, and connections added allure to the salons. Margaret was delighted to hear that Correa da Serra, whose scientific and literary acquirements attracted her more than his political leanings, "is very impatient to be [invited] here." The elderly cleric's continental saviorfaire, not his radical political leanings, made him a treasured confidante. In the verbal tête-à-tête of their salons the Abbé could be expected to give at least as well as he received. Of course, such a noted intellect could not fail to draw other enlightened figures into the Carolinians' Philadelphia circle. $^{45}$

The attraction of these elderly men was thus ideological and, at the same time, intensely personal. Both widows felt keenly the loss of their husbands. In part, the company of Vaughan, Short, and Correa served as a platonic replacement for their refined mates. "A sensible, well-informed, polite old man is a treasure, I think, in society, \& particularly in a large female family like ours," Margaret wrote her sister in 1812. The presence

44 Joseph Francisco Correa da Serra to John Vaughan, Dec. 17, 1815, American Philosophical Society Archives (American Philosophical Society Library, Philadelphia); "Recollections of Joshua Francis Fisher," Cadwalader Collection; Charlotte and Margaret Manigault to Elizabeth [Manigault] Morris, Apr. 11, 1816, Manigault Family Papers. On the Izards' relations to Vaughan, see, for example, Ralph Izard to John Vaughan, Aug. 25, 1793, Madeira-Vaughan Collection, (American Philosophical Society). Vaughan was a family friend even before the federal government came to the city. During a short layover at the City Tavern in Philadelphia, Gabriel Manigault noted that "Mr. John Vaughan called several times on us." See "Tour to the Northward, 1783; and again in 1789 and 1791," [Oct.] 21, 1789, Manigault Family Papers.

${ }^{45}$ Margaret Manigault to Elizabeth (Manigault) Morris, Nov. 7, 1812, Manigault Family Papers; Margaret Manigault to Elizabeth (Manigault) Morris, Mar. 24, 1813, Manigault-Morris-Grimball Family Papers. 
of elderly men of learning was especially appreciated during the war years of 1812-1815, when military service required the Manigault men to endure extended absences from their family. ${ }^{46}$ The two widows (Margaret turned forty-four in 1812, her mother sixty-seven) surrounded themselves with men of their own generation who shared their disdain of declining civility. Both the women and their elderly male friends, moreover, were committed to the establishment of an American privileged class. Even with Correa's élan, it is unlikely that he would have become such an intimate to the Manigault circle had his republican leanings not obscured a deeper convergence of vision. Like the Boston elites studied by Ronald Story, individual proclivities - even political differences - belie a fundamental agreement on core principles that binds together elite groups ${ }^{47}$ In this case, these gentlemen - even Correa-shared the nationalist bent that distinguished the American upper strata until, and in some cases into, the Civil War.

Conversation and verbal repartee were only the most obvious ways that these salonierres sought to reinforce gentry ways. The Manigaults implicitly understood that ideology transcends formal modes of thought and is embedded in words, expressions, behaviors, and materials-the stuff of everyday life. Hence the family devoted special attention to ostensibly private, nonpolitical aspects of gentry culture-dancing, singing, sociability, instrumental music, and the like. Their affairs were eclectic, embracing these so-called "accomplishments" as well as discussion and disputation. The propagandists of the emerging middle class understood these connections as well. They reinterpreted Chesterfield's code, making refinement a reflection of inner merit and piety by purging it of its aristocratic associations, emphasis on display, and glorification of leisure. A mid-century etiquette advisor maintained that "refined society" was not "those whom you can find in the ball-room, in the theatre, in the crowded party, ... [but] those who make you feel at ease in their society, while at the same time they elevate your aims and polish your manners." Gentility was not a product of family heritage, privilege, and refined company; rather, "those who are the real disciples of Christ cannot fail to be truly polite." As Dallett Hemphill, Jacquelyn Miller, and Richard Bushman have

46 Margaret Manigault to Elizabeth (Manigault) Morris, Nov. 7, 1812, Manigault Family Papers. Margaret's son Gabriel Henry served as an aide under her brother, General George Izard, who served in Wade Hampton's command. Her son Charles served in the Washington Guards and spent much of his service around Philadelphia. On the Federalist orientation of these companies, see Koschnik, "Fashioning a Federalist Self," 32-39.

${ }^{47}$ Story, "Class and Culture in Boston"; Story, The Forging of an Aristocracy; see also Jaher, The Urban Establishment, chap.1. 
shown, the middle-class redefinition of gentility-what became known as "respectability"-involved a rejection of certain aristocratic practices, especially leisure and sensual enjoyments such as gambling and drinking. For centuries privileged orders had insisted on enjoying themselves in ways the middle class would come to see as corrupt and self-indulgent. Though the Manigaults were hardly sensualists, they did assert the right of the aristocracy to dress well, drink, and carouse. Such were the perks of privilege. $^{48}$

Hence their salons elicited judgments on dress, manners, and behavior whose meaning transcended mere fashion. A tasteless gown, a gaudy necklace, brilliant wit-all contained hidden meanings exposing the shortcomings and strengths of the republic's gentry. One family friend, James Cuthbert, "looked very genteel" at one affair, but the salutary effect of this young American was offset by the lackluster appearance of "Mrs. N[icholas] Biddle [who] wore a common velvet dress" to the same affair. Such an eminent lady should have exhibited better taste, and her failure reflected badly on American gentlewomen. Biddle's inadequacy was all the more glaring in light of the company's dazzling foreign guests. Madame de Kantzow, a family favorite, "impressed all, who had not seen her before. Her resplendent charms were all displayed, \& ornamented with a handsome neat lace. ... Diamonds innumerable sparkled in her small shaped hands." Madame de Onis adorned herself in a "white satin" dress with a "rich lace robe over it," a similar though more understated radiance than that projected by her Scandinavian friend. In their mannerisms, too, Americans seemed to reflect the general coarseness of their popular culture. One prominent gentlewoman observed by Harriet Manigault at a ball, "has grown exceptionally clumsy, \& exposes her great \& now frightful neck in an astonishing degree, \& is so out of time!" This matron's wealth could not redeem her diverse social sins-on the contrary. Her failure to

${ }^{48}$ Ladies' Vase: or, Polite Manual for Young Ladies. Original and Selected. by an American Lady (Lowell, 1843), 13-24, 8; Bushman, Refinement of America, esp. chaps. 10 and 11; Hemphill, "Middle Class Rising." Isaac, The Transformation of Virginia is particularly good on the conflict between gentry and evangelical mores. Harold Perkin suggests that aristocratic leisure involves the right to do whatever one chooses, including nothing at all. Perkin, The Origins of Modern English Society (1969; rep., London, UK, 1985), 55. Wood, The Radicalism of the American Revolution, 277, suggests that American bluebloods tried to adopt European ideas of leisure but saw them stigmatized as "idleness" by the lower orders. Critics of gentility often represented the rich as corrupted by sensuality. See, for example, George Lippard, The Quaker City; or, the Monks of Monk Hall: A Romance of Philadelphia Life, Mystery, and Crime, ed. David S. Reynolds (1845; rep. Amherst, 1995). 
reconcile her wealth with her manners exposed the inadequacy of aristocracy in the young republic. If the gentry behaved like commoners, the latter might ask, why should they respect its claims to privileged status? ${ }^{49}$

In mixed company of adolescents and adults, instrumental music, not dancing, predominated. At one "charming" and "sociable" gathering, the proud parent related, Harriet Manigault and a friend played harp and piano together to "perfection.... [Harriet] says she never was so much flattered in her life." Though music provided their company with entertainment and the young players with approbation, it did more important cultural work. The Manigault letter writers took special note of occasions when their circle collaborated with their European friends. The virtues Margaret Manigault discerned in the young Kantzow ladies exemplified those she wished to see in her own set. "They play \& sing without pretension," she noted. "Their attitudes are all ease, \& their ease is not diminished by the precision of their steps." Music and dance united American and Old World bluebloods in an Atlantic cosmopolitan community. The expense and time involved in educating children in traditional forms of singing, dancing, and musical skills limited their attainment to the wealthy. For the same reasons, they were reviled by the middling orders. American youth accomplished in such cultivated arts distinguished themselves from the common herd and, their parents hoped, became associated with aristocracy. ${ }^{50}$

The family's desire to construct a national identity that merged European élan with republican virtues complicated their more immediate project of upholding standards of good taste at a time when the very terms of gentility were contested. The Manigaults' ambiguous stance toward the ancien régime, a tension felt by most members of the gentry, confounded this goal. Admiration sometimes threatened the construction of a distinctive American nationalism. For all their wealth and cultivation, after all, American bluebloods never would be titled aristocrats, but in Europe

49 [Margaret Manigault to Elizabeth (Manigault) Morris], Dec. 21, 1813, ManigaultMorris-Grimball Family Papers; Charlotte Manigault and Margaret Manigault to Elizabeth (Manigault) Morris, Apr. 11, 1816, Manigault Family Papers.

${ }^{50}$ Margaret Manigault to Charlotte-Georgina (Izard) Allen Smith, Dec. 19, 1812, Margaret Manigault to Charlotte-Georgina (Izard) Allen Smith, Nov. 20, 1813, Manigault Family Papers. All social ranks enjoyed music, but different contexts determined, in part, the substance of the entertainment. "[T] he activities of polite entertainment were not in themselves distinctive," observes Richard Bushman. Their substance-classical music, elaborate dance -and their contexts-elegant parlors, ballrooms-made them so. Bushman, Refinement of America, 51. 
that label had very specific connotations. Even before Chesterfield, Americans of means had slavishly adopted the ways of Europeans of rank to claim some of that legitimacy for themselves. Indeed, much of the force of the middle-class critique of genteel manners emerged from the sense that, imitative as gentility was, it was inherently unAmerican. ${ }^{51}$

With Philadelphia considered a "more agreeable place of residence" than Washington by the foreign diplomatic corps, the city offered Americans the opportunity to witness first hand European ways-both the elegant and the decadent. As an example of the latter, Margaret offered to a friend the spectacle of "Ladies perform[ing] military evolutions at the Riding School" in Charleston. "It is well that our government in its wisdom decreed a non-intercourse," she wrote in dismay of Jefferson's embargo, "for we make such alarming progress in civilization" by being so "imitative, so emulative" of "Paris[ian] ... fashion[s]." To the chagrin of some gentlefolk, the diplomats' presence set off a period of even more crass imitation. "The prevalent disposition to imitate the manners of Europe, has caused the introduction of many frivolous customs and amusements in our city," observed one Philadelphia social critic. Only the gentry of old wealth was secure enough in their identity to incorporate the foreigners' cultivation while preserving republicanism at home-or so they believed. Still, if their example sometimes threatened to overwhelm the young republic with dissipation, European elites also presented Americans with a template from which they could fashion a new gentility combining continental fashion and American virtue. ${ }^{52}$

${ }^{51}$ On the limitations faced by American "aristocrats" in the colonial and early Republican years, see Gary J. Kornblith and John M. Murrin, "The Making and Unmaking of an American Ruling Class," in Alfred Young, ed., Beyond the American Revolution: Explorations in the History of American Radicalism (DeKalb, 1993), 27-79. American houses turned out eighteen editions of Letters to His Son by the Earl of Chesterfield; On the Fine Art of Becoming a Gentleman, originally published in 1774. On the allure of the Earl in America, see Bushman, Refinement of America, 36-38. W.J. Rorabaugh argues that Americans preferred distilled spirits over wine partially because of the aristocratic connotations associated with the latter. Rorabaugh, The Alcoholic Republic: An American Tradition (New York, 1979), 100-06, 111-12.

52 Hall, Aristocratic Journey, 140; Margaret Manigault to Mrs. Pinckney, Apr. 2, 1809, Manigault Family Papers; Peter Atall [Robert Waln, Jr.], The Hermit in America, on a Visit to Philadelphia. Containing, some Account of the Human Leeches, Belles, Beaux, Coquettes, Dandies, Cotillion Parties, Supper Parties, Tea Parties, \&c \&c of that Famous City (Philadelphia, 1819), 146. Literature on the French in America focuses on the 1790s, though Bonapartist and Bourbon exiles also flocked to Philadelphia in the early decades of the nineteenth century. $\rightarrow$ Catherine A. Hebert, "The French Element in Pennsylvania in the 1790s: The Francophile Immigrants' Impact," Pennsylvania Magazine of History and Biography, 108 (Oct. 1984), 451-69; and J.G. Rosengarten, French Colonists and Exiles 
Doubtless the Manigaults' extensive travels in Europe, their fluency in French, and their aristocratic temperament helped their foreign friends feel welcome in their homes. But European travel hardly distinguished the Carolinians from others in their circle. Many genteel Americans, northern and southern, made the Grand Tour. Besides befriending Philadelphia's resident foreign diplomats, the group established close relations with the large body of Francophone exiles and refugees who settled in the city. Prominent among the former group, not surprisingly, were several diplomatic families whose children found close friends in Harriet and Charlotte, the youngest Manigault daughters. If, as many foreigners complained, Americans were overly sensitive to their opinions regarding the new nation, they were unlikely to suffer such badgering on Spruce Street. The denizens of that street and its environs found "something very pleasing in the society of well bred foreigners," as one observed, for "if they see that you wish to please them, \& to place them at their ease, they are grateful, \& enjoy the happy privilege." On Spruce Street, English and continental gentlefolk found entertainments reminiscent of European salons and company that wished to employ their old world sophistication to the cause of new world nationalism. ${ }^{53}$

At least two impulses spurred the Manigaults in founding their salon: establishing a national upper-class culture based on close ties of kinship and friendship between east coast elites, and reinvigorating their Federalist circle in an era of Republican ascendancy. Judged by the former standard, their Philadelphia "colony" must be judged a smashing success. Margaret's daughter Harriet married Samuel Wilcocks, a young Philadelphia lawyer from a prominent family, and settled in Philadelphia. Their daughter, Charlotte, became a noted Philadelphia belle in her own right, closely tied to both eminent Philadelphia families like the Ingersolls while still retaining her Carolina roots. The social bonds between like-minded families, however, proved even more durable and wide-ranging than blood ties. Defying the drift of sectional feelings in the decades before the Civil

in the United States (Philadelphia, 1907).

${ }^{53}$ Margaret Manigault to Charlotte (Manigault) Allen Smith, Sept. 11, 1814, Manigault Family Papers. Basil Hall found that he "was often surprised to discover the degree of anxiety with which the opinions of a foreigner were sought for with regard to many insignificant topics, upon which his sentiments might have been thought very little." Hall, Travels in North America in the Years 1827 and 1828 (3 vols., Edinburgh, 1829), II, 339-40. On southerners and the Grand Tour, compare William R. Taylor, Cavalier and Yankee: The Old South and American National Character (1961; rep., New York, 1963), 27-32; with Michael O'Brien, "On the Mind of the Old South and its Accessibility," in O'Brien, ed., Rethinking the South, 35-36. 
War, ties between northern and southern bluebloods actually grew stronger, not weaker, in those years. Their salon helped cement what the historian of medicine Richard Shryock called a "restricted sort of coast-line sectionalism, based upon common colonial traditions ... an urban culture common to both sections" existing until the eve of the Civil War. ${ }^{54}$

The bonds between northern and southern bluebloods can be most clearly seen in the diary of Sidney George Fisher, the cousin of the Manigaults' guest Joshua Francis Fisher. His association with the Middleton and Izard families can be traced back to the friendship of his uncle, George Harrison, to those families in the early years of the century, when he was a frequent guest at Clifton and on Spruce Street. He often socialized with the Izards while vacationing at Newport. Moreover, Sidney Fisher's cousin Joshua married Elizabeth Middleton, the daughter of Henry Middleton and a frequent guest of the Manigaults. But Fisher's ties to planter families were not restricted to this narrow circle. His diary entries from the 1830s and 1840s focus on his busy social schedule in which the names of eminent southern families figure prominently. These families journeyed to Philadelphia for a number of reasons. Partly because of the Manigault salons, American social elites shared a common culture. The historian Bertram Wyatt-Brown observes that southern "assumptions of status, taste, and good breeding ... were quite compatible with the criteria prevailing in the salons of Boston, New York, Philadelphia, and London." Most importantly, Philadelphia remained the center of leisure class life in antebellum America. As Izard Middleton reported after a visit to Harriet Wilcocks in 1834, Philadelphia was "the only genteel place I have seen since I left Ch[arleston]."

Judged by their second goal-the revival of Federalism and the reassertion of aristocratic values generally-the legacy of the Manigault salon is at best ambivalent. The dismal record of the Federalist party in this era-particularly in the South, the Manigaults' home region-speaks for itself. And though attacks on privilege reached a frenzied pitch in the early republic, criticism of the leisure class grew both more sophisticated

${ }^{54}$ Letters of Richard D. Amold, M.D., 1808-1876, Mayor of Savannah, Georgia, First Secretary of the American Medical Association, ed. Richard H. Shryock (Durham, NC, 1929), 9. The diaries of Harriet Manigault Wilcocks and her daughter Charlotte Wilcocks McCall are held at the Historical Society of Pennsylvania.

${ }_{55}$ Wyatt-Brown, House of Percy, 10; Izard Middleton to Nathaniel Russell Middleton, June 8, 1834, Nathaniel Russell Middleton Papers, Southern Historical Collection (Wilson Library, University of North Carolina, Chapel Hill), A Philadelphia Perspective: The Diary of Sidney George Fisher, Covering the Years 1834-1871, ed. Nicholas B. Wainwright (Philadelphia, 1967). 
and more subversive in later years. Instead of rejecting the value of refinement altogether, the critics of the 1830s and 1840s purged gentility of its decadent excesses and its association with political privilege. The Manigaults sought to preserve the social elite's cultural authority by maintaining refinement as the expression of a privileged caste. Emerging groups, however, were rejecting that authority, partly by fashioning a version of refinement that discredited the aristocratic associations of the old code.

On the other hand, the Manigaults' determination and initiative in defending the virtues of privilege stands in stark contrast to the inertia and anomie that marked upper-class life in later decades. As the withdrawal of Federalists from Fourth of July celebrations following Jefferson's victory attests, conservatives were already disengaging from public, political activity on behalf of elitist principles. That limited withdrawal pales, however, in comparison to the wholesale capitulation that characterized the privileged orders in the antebellum era. Although we may deplore the elitist principles that the Manigaults endorsed, they continued to embrace them in the face of popular derision. They kept the faith. Sidney Fisher's diary, by contrast, documents the sterility and myopia that characterized leisure-class life in the later period. By the 1830s, the upper crust-in the North, at least-had withdrawn into itself, its affairs shorn of public significance. The self-imposed exile of Philadelphia bluebloods led Harriet Martineau to observe acidly that " $[t]$ he republic suffers no further than by having within it a small class acting upon anti-republican morals, and becoming thereby its perverse children, instead of its wise and useful friends and servants." agreed.

The gradual introduction of young men and women into the social whirl, the carefully chosen assembly of family and friends, the establishment of a reactionary salon, and their choice of Philadelphia over New York and Charleston all speak to the Manigaults' efforts to reproduce in the next generation their own experience as a gentry class. But it was not to be. Only three of Margaret Manigault's children-Charles, Harriet, and Harry-survived her when she died at her Spruce street home in 1824. Of those three only Charles, who lived well into Reconstruction, lived past 1835. They were hardly representative of Americans generally, but they were well-placed within the upper echelons of American society. Perhaps the early national gentry could have shaped America's antebellum destiny more effectively had they more articulate and aggressive propagandists of

\footnotetext{
${ }^{56}$ Harriet Martineau, Society in America (2 vols., New York, 1837), I, 172-73.
} 
the Manigaults' stripe. But the difficulties they faced were reflected in the very structure of the salon itself: dedicated to elitism, its influence was restricted by the demands of exclusivity.

The American gentry sought an aristocratic way of life, and they wanted the lower orders to ratify that pursuit through deference. In this respect scholarly efforts to disprove the "egalitarian myth" popularized by de Tocqueville miss the point. The leisure class tried to reproduce, as best they could, the manners of the colonial and early national gentry. But the experience of riches is not the experience of aristocracy. Money and property confer in plenty opportunities closed to others, but affluence alone cannot match the power, status, wealth, and entitlement that defines aristocracy. For the Manigaults and their circle, as for other wellborn old American families from Boston to New Orleans, the proper society resembled one of accepted hierarchies of wealth, taste, and family, bound together by reciprocal relationships of deference and protection. Perhaps they would have been better served had they lived according to an aphorism entered into the commonplace book of Charles Manigault: "I shall cherish no ambition of living in the minds and memories of men, but I shall endeavor with all my efforts to obtain that living grace which can only come into the heart from my soul." ${ }^{, 57}$ Unfortunately for their peace of mind, the family's social identity precluded such a compromise.

${ }^{57}$ Charles Manigault, Catalogue, n.d., Manigault Family Papers. For astute criticisms of Pessen, see Wood, Radicalism of the American Revolution, 342-43; Jaher, The Urban Establishment, 68-71; and Gallman, "Professor Pessen on the 'Egalitarian Myth"'; Gallman, "The 'Egalitarian Myth,' Once Again." 